\title{
Fenomena Pentakdisan Turāth di Dayah Tradisional Aceh
}

\section{The Sacralization of Turāth at Traditional Dayah of Aceh}

\author{
Lazuardi Muhammad Latif \\ Department of Al-Quran and Al-Hadith, Academy of Islamic Studies, University of \\ Malaya, 50603 Kuala Lumpur, Malaysia. \\ lazuardimohamed@gmail.com \\ Faisal Ahmad Shah \\ Department of Al-Quran and Al-Hadith, Academy of Islamic Studies, University of \\ Malaya, 50603 Kuala Lumpur, Malaysia. \\ faisalas@um.edu.my
}

DOI: https://doi.org/10.22452/usuluddin.vol49no1.3

\begin{abstract}
The sacralization of turāth refers to a form of unconditional admiration toward and blind acceptance of the content of turāth books, with the assumption that the books are free of mistakes or inaccuracies. The traditional Dayah of Aceh, a highly valued educational Islamic institution in the eyes of the Acehnese people, plays a pivotal role in promoting various religious understandings as prescribed in turāth books. In order to see to what extent this assumption is true, this field study attempts to investigate the use of turāth at Dayah Mudi Mesra, Samalanga, Aceh. This Dayah has earned much respect and trust from today's Acehnese society due to its role in the teaching of Fikah. The study was carried out to identify the perceptions of the ulama at the traditional dayah toward the position of turāth books in their study of Islamic sciences, especially fikah. This qualitative study employs various data collection methods including literature review, interviews, documentation and observations. In addition, inductive, deductive, and comparative methods were used for data analysis. The study found that the ulama of the traditional dayah in Aceh, in their studies of Islamic sciences, especially fikah, had regarded turāth books as being on par with hadith.
\end{abstract}

Keywords: Sacralization, turāth, Dayah of Aceh

\begin{abstract}
Abstrak
Pentakdisan kitab turāth merupakan upaya melakukan pentaksuban kepada seluruh isi kandungan kitab turāth dan memaksumkannya. Dayah Tradisional Aceh adalah sebuah institusi pengajian Islam yang dipandang tinggi di mata masyarakat Aceh dalam mendedahkan pelbagai kefahaman agama yang berpedoman kepada kitab turāth. Kajian ini merupakan
\end{abstract}


kajian lapangan yang mengambil tempat di Dayah Mudi Mesra Samalanga Aceh, kerana pengaruhnya yang besar bagi masyarakat di masa kini terutamanya dalam permasalahan fikah. Kajian ini dijalankan untuk mengenalpasti pandangan ulama dayah tradisional tentang kedudukan kitab turāth sebagai pedoman dalam pengajian ilmu-ilmu keislaman terutamanya fikah. Kajian ini merupakan penyelidikan kualitatif dengan kaedah pengumpulan data dari sumber perpustakaan, temubual, dokumentasi, dan pemerhatian. Manakala kaedah analisis data dilakukan secara induktif, deduktif, dan komparatif. Kajian ini mendapati bahawa pandangan ulama dayah tradisional Aceh tentang kedudukan kitab turāth sebagai pedoman dalam pengajian ilmu-ilmu keislaman, terutamanya fikah, adalah setaraf dengan hadith.

Kata Kunci: Pentakdisan, kitab turāth, Dayah Aceh

\section{Pendahuluan}

Perbahasan tentang kitab turāth yang wujud dalam Islam adalah suatu perbahasan tentang pemikiran dan kefahaman yang telah dicapai oleh generasi terdahulu. Ianya wujud dan termaktub dalam karya-karya mereka yang dapat menjadi pengetahuan dan pedoman bagi generasi setelah itu. Maksud daripada perkataan pentakdisan turāth dalam tajuk makalah ini adalah upaya melakukan pentaksuban dalam berpedoman kepada seluruh isi kandungan kitab turāth dan memaksumkannya daripada sebarang kesalahan.

Bakr Zaki 'Iwāẹ dalam kitab al-Turāth al-Islāmī Bayna alTaqdīr wa al-Taqdīs membahagikan pandangan umat Islam dalam memahami kedudukan kitab turāth kepada tiga golongan. Iaitu:

Pertama; Mereka ini terdiri dari orang awam daripada kebanyakan umat Islam. Golongan ini berpandangan bahawa kitab turāth adalah suatu karya suci yang tidak dapat disentuh dan dikritik sembarangan. Ianya adalah bentuk daripada wajah Islam dan sebarang kritikan yang ditujukan kepadanya menjadi kritikan kepada kebenaran Islam. Oleh itu, ianya tidak dapat diganggu dan wajib diterima seperti semula ada.

Kedua; Pelopor golongan ini wujud di negeri Barat, tetapi pengikutnya ada di Timur Islam yang tergabung dalam kelompok sekularis, modernis, dan post modernis. Golongan ini berpandangan wajib memutuskan pertalian apa jua yang berkenaan dengan kitab turāth. Umat Islam wajib membuat 
semula kefahaman baru yang bersesuaian dengan zaman kini dan dapat diterima oleh tuntutan kehidupan moden.

Ketiga; Kelompok ini dianggap sebagai golongan wasatiyyūn. Mereka berpandangan bahawa kedudukan kitab turäth hanyalah sebagai karya manusia. Apa jua yang termaktub dalam kitab turāth tidak dapat diterima sebagai kebenaran mutlak, juga tidak dapat ditolak dan dipandang salah secara mutlak. Bagi golongan ini, kitab turāth adalah suatu bekal kekayaan yang tidak boleh disia-siakan. Ianya adalah pangkal yang tidak boleh dicabut daripada akar dan juga seumpama pakaian yang tidak boleh dilepaskan.

Dalam pada itu, golongan ini berpandangan sentiasa wajib membuat penyelidikan terhadap tingkat kebenaran yang dikandungi oleh kitab turāth. Seumpama pakaian yang sentiasa wajib dibersihkan daripada kotoran yang melekat padanya. Para ulama yang terhimpun dalam kelompok ini tidak pernah menganggap para ulama penulis kitab turāth sebagai manusia yang maksum daripada kesalahan. Dalam masa yang sama pula tidak pernah menganggap kefahaman mereka keliru dalam semua perkara. Pelopor golongan ini adalah para ulama hadith seperti Bukhari dan Muslim. Keduanya sangat berperanan dalam mengkritisi riwayat-riwayat yang didapati dari generasi sebelumnya, juga memilih dan menyusun tingkat kebenarannya pada beberapa peringkat. ${ }^{1}$

Bakr Zakī 'Iwād menyebutkan, kitab turāth akan sentiasa memberikan dampak negatif apabila umat atau pengikut suatu mazhab berpaling dari sikap mentakdirkan (menghargai) kepada sikap mentakdiskannya. Menurut beliau, fenomena pentakdisan tersebut dapat dilihat dalam beberapa hal berikut:

i. Tidak mengambil kira dengan perubahan semasa dan sentiasa berpedoman pada pendapat lama. ${ }^{2}$

ii. Menempatkan pendapat mazhab pada peringkat Nușuṣ alSharī ${ }^{3}$ 
iii. Sentiasa membela pendapat mazhab yang bercanggah dengan dalil aqli dan naqli. ${ }^{4}$

iv. Memaksakan orang lain mengamalkan pendapat mazhab yang diikuti. ${ }^{5}$

v. Menganggap upaya tajdìd dan para mujaddīd melencong dari kefahaman Islam. ${ }^{6}$

vi. Membangkitkan semula pendapat-pendapat salah yang telah pupus ditelan zaman.

vii. Melampau-lampau dalam memuji kitab turāth dan pengarangnya hingga ke tahap tidak dapat dikritik. ${ }^{8}$

Berasaskan apa yang diketengahkan oleh Bakr Zakī 'Iwāḍ, maka sikap paling benar yang wajib diamalkan berkenaan kedudukan isi kandungan kitab turāth adalah berupaya mentakdirkannya. Manakala para pengikut mazhab apa jua yang memiliki amalan bersesuaian dengan kriteria-kriteria pentakdisan (Ma'àlim al-Taqdīs) sepertimana telah didedahkan, maka bermakna ianya telah melakukan upaya pentakdisan.

Dayah Tradisional Aceh adalah institusi pendidikan agama Islam yang memiliki pemerhatian yang tinggi terhadap pengkajian kitab-kitab turäth, terutamanya berkenaan dengan ilmu tasawuf, tauhid, dan fikah. Kitab-kitab yang dijadikan rujukan dalam pengajian adalah semua yang berbentuk turāth yang dianggap muktabar oleh ulama kalangan dayah tradisional. Khususnya dalam pengajian ilmu fikah, kitab-kitab yang dijadikan rujukan dalam pengajian adalah dikhaskan pada kitab-kitab ulama dari golongan al-Shāfi'iyyah yang telah mendapatkan pengiktirafan daripada kalangan dayah tradisional sendiri secara turun temurun. ${ }^{9}$ Kerana kedudukan pengajian fikah yang lebih dominan daripada

Bakr Zakī 'Iwāḍ, al-Turāth al-Islāmī Bayna al-Taqdīr wa al-Taqdīs, 73. Bakr Zakī 'Iwāḍ, al-Turāth al-Islāmī Bayna al-Taqdīr wa al-Taqdīs, 77. Bakr Zakī 'Iwāạ, al-Turāth al-Islāmī Bayna al-Taqdīr wa al-Taqdīs, 80. Bakr Zakī 'Iwāḍ, al-Turāth al-Islāmī Bayna al-Taqdīr wa al-Taqdīs, 83. Bakr Zakī 'Iwāọ, al-Turāth al-Islāmī Bayna al-Taqdīr wa al-Taqdīs, 85. Untuk melihat lebih rinci tentang kurikulum dan kitab-kitab yang dijadikan rujukan di dayah pada setiap peringkat dan darjah sila merujuk kepada Tim Penulis, Buku Pedoman Pengembangan Silabus dan Kurikulum Pendidikan Dayah (Banda Aceh: Badan Pembinaan Pendidikan Dayah Aceh, 2012). Lihat juga Zahrul Fuadi Mubarrak et al., "Profil Dayah Mudi" (Mesjid Raya Samalanga: Lajnah Pengembangan Dakwah MUDI, 2018). 
pengajian ilmu tasawuf dan tauhid, maka pandangan kalangan dayah tradisional tentang isu-isu fikah tampak lebih menonjol dalam kalangan masyarakat.

Jika wujud satu amalan berkenaan dengan hukum fikah, maka sangat mudah dijejaki bahawa amalan-amalan tertentu tersebut adalah suatu tradisi yang merujuk kepada kefahaman ulama kalangan dayah tradisional. Seperti tradisi pembayaran kifarah solat kepada orang yang meninggal dunia yang kerap diamalkan di kalangan masyarakat Kabupaten Aceh Besar, ${ }^{10}$ tradisi $i$ 'a dah solat Zohor setelah melakukan solat Jumaat yang menjadi ciri khas amalan kalangan dayah tradisional dan berlaku pula pada amalan sebahagian masyarakat di kampung-kampung, ${ }^{11}$ pendapat tidak sah pembayaran zakat fitrah dengan wang, ${ }^{12}$ dan masih banyak lagi yang tiada mungkin penulis sebutkan semua di sini.

Dilimunazar, "Tulak Breuh (Tradisi Ritual Keagamaan yang Masih Dilaksanakan di Provinsi Aceh)", laman sesawang Steemit, dicapai 20 September 2020, https://steemit.com/culturevulture/@ dilimunanzar/tulakbreuh-tradisi-ritual-keagamaan-yang-masih-dilaksanakan-di-provinsi-aceh; "Hukum Kafarah Shalat dan Puasa | Muzakarah Ulama Se-Aceh VII", laman sesawang Youtube, https://www.youtube.com/watch?v=yL7yCUw9vOw, dicapai 20 September 2020; "Wajibkah membayar kafarat orang yang meninggalkan shalat?- Tu Sop Jeunieb", laman sesawang Youtube, https://www.youtube.com/watch?v=4zHCOhLhu40, dicapai 20 September 2020.

11 "Hukum $i$ 'adah Shalat Zohor setelah Jumat - Abu Mudi Menjawab", laman sesawang Youtube, https://www.youtube.com/watch?v=_MTuiRhKKbg, dicapai 20 September 2020; "Hukum iadah Shalat DZohor Sesudah Shalat Jumat, Muzakarah Ulama Se-Aceh IV", laman sesawang Youtube, https://www.youtube.com/watch?v=CwI6s_lrZOo, dicapai 20 september 2020 .

12 Nuruzzahri, "Implementasikan Secara Masif Fatwa MPU Aceh tentang Zakat Fitrah" laman sesawang Aceh Tribunnews, dicapai 25 Ogos 2018, http://aceh.tribunnews.com/2017/06/20/implementasikan-secara-massiffatwa-mpu- aceh-tentang-zakat-fitrah; Lihat "Lajnah Bahtsul Masail Lembaga Pendidikan Islam Ma'hadal Ulum Diniyah Islamiyah," laman sesawang Ibm Mudimesra, dicapai 25 Ogos 2018, http:// lbm.MUDImesra.com//2012/08/diskripsi-masalah.html; Lihat Serambi Indonesia, Rubrik Serambi Kuta Raja, Selasa 28 Mei 2019 / 23 Ramadhan 1440 H, 3; Lihat Serambi Indonesia, Rubrik Nusantara, Jumat 31 Mei 2019 / 26 Ramadhan $1440 \mathrm{H}$, 4; Lihat Serambi Indonesia, Rubrik Serambi Nusantara, Jumat 24 Mei 2019 / 19 Ramadhan 1440 H, 3; Lihat Abu Mudi, "Zakat Fitrah dalam Pandangan Imam al-Shafi'i dan Imam Abu Hanifah", 
Pandangan-pandangan ulama kalangan dayah tradisional berkenaan isu fikah sepertimana disebutkan telah menggerakkan minat pengkaji untuk mengkaji lebih terperinci tentang pandangan mereka terhadap kedudukan apa jua yang termaktub dalam kitab turäth. Berasaskan hal ini, maka yang menjadi soalan dalam kajian ini adalah: Bagaimana ulama kalangan dayah tradisional Aceh memandang kedudukan kitab turāth dalam pengajian ilmu-ilmu keislaman terutamanya masalah fikah.

\section{Skop dan Metodologi}

Skop perbincangan dalam makalah ini adalah tentang pandangan ulama kalangan dayah tradisional Aceh berkenaan kedudukan kitab turäth dalam pengajian, terutamanya dalam pengajian fikah. Dayah Ma'hadal Ulum Diniyah Islamiyah Mesjid Raya (MUDI MESRA) Samalanga, Kabupaten Bireuen, Provinsi Aceh adalah sebuah institusi yang dijadikan sampel penyelidikan bagi menggambarkan pandangan kebanyakan institusi dayah tradisional Aceh lainnya. Ini dilakukan berasaskan kedudukannya sebagai institusi dayah tradisional terbesar dan sangat memegang peranan saat ini di Aceh. Sama ada peranan yang dimainkan secara langsung oleh ulama Dayah MUDI MESRA sendiri, mahupun peranan yang dimainkan oleh para alumni yang menjadi pengetua pada pelbagai dayah lain.

Penyelidikan ini menggunakan pendekatan kualitatif ${ }^{13}$ berbentuk deskriptif analisis. Metode pengumpulan data dijalankan secara Perpustakaan (library research), Temu bual

laman

Youtube, https://www.youtube.com/watch?v=XV4RrvnUvno, dicapai 20 september 2020; Lihat "Hukum Zakat Fitrah dengan Uang [Abiya Muhammad Baidhawi]", laman sesawang Youtube, https://www.youtube.com/watch?v=ED7kXJvFzbg, dicapai 25 Ogos 2018; Lihat "Fatwa MPU Aceh Nombor 13 Tahun 2014 Tentang Zakat Fitrah", laman sesawang MPU Aceh, dicapai 22 Ogos 2020, https://mpu.acehprov.go.id/; Lihat "Keputusan Kantor Kementerian Agama Kota Banda Aceh", laman sesawang Aceh Tribunnews, dicapai 22 Ogos 2020, https://aceh.tribunnews.com/2020/05/11/di-banda-aceh-zakat-fitrahtak-bisa-dibayar-uang-harus-langsung-beras

13 Lebih lanjut tentang analisis data metode kualitatif sila merujuk pada Miles dan Huberman, Qualitative Data Analysis: A Source Book of New Methods (California: SAGE Publication, 1984). 
mendalam (deep interview) dengan para guru senior iaitu dengan empat orang dari 10 (sepuluh) dewan guru yang terlibat langsung dalam proses pengajian subjek fikah dan hadith untuk pelajar tingkat tinggi. Temu bual juga dilakukan dengan seorang alumni yang telah berjaya menjadi pensyarah senior di salah satu Universiti Agama terkemuka di Aceh. Sebagai data pembanding, temu bual juga dilakukan dengan dua ulama ahli dayah di luar MUDI MESRA. Untuk menjaga privasi, semua data yang bersumber daripada temu bual didedahkan dengan cara menyamarkan nama sampel temu bual (pseudonym). ${ }^{14}$ Kaedah pengumpulan data juga dijalankan dengan cara melakukan Pemerhatian (observasi), Dokumentasi seperti dokumen yang terdapat dalam laman sesawang akhbar, media cetak, laman sesawang Lajnah Bahsul Masail (LBM) Dayah MUDI MESRA dan video guru-guru dalam memberikan pengajian kepada masyarakat. Manakala Metode Analisis Data dijalankan dengan menggunakan beberapa kaedah, iaitu: Kaedah Induktif, ${ }^{15}$ Deduktif, ${ }^{16}$ dan Komparatif. ${ }^{17}$

\section{Hasil Dapatan}

\section{Kedudukan Kitab Turāth dalam Pandangan Ulama Terdahulu} Para imam mazhab mahupun ulama mujtahidūn lainnya tiada pernah bermaksud untuk diikuti sepertimana yang berlaku kemudian pada para pengikut mazhab. Mereka tidak pula

Semua data dalam kajian ini adalah sebahagian daripada data tesis yang pengkaji jalankan untuk menyelesaikan peringkat ijazah kedoktoran di Akademi Pengajian Islam Universiti Malaya.

15 Kaedah ini adalah untuk membuat kesimpulan daripada bukti-bukti yang bersifat khas bagi mencari kesimpulan yang bersifat am. Lihat Muhammad Majid Konting, Kaedah Penyelidikan Pendidikan (Kuala Lumpur: Dewan Bahasa dan Pustaka, t.t.), 13.

16 Kaedah ini adalah untuk membuat kesimpulan daripada bukti-bukti yang bersifat am bagi mencari kesimpulan yang bersifat khas. Lihat Muhammad Majid Konting, Kaedah Penyelidikan Pendidikan, 13.

17 Kaedah ini adalah suatu cara untuk membuat kesimpulan dengan melakukan perbandingan terhadap sebarang data yang diperolehi. Kaedah komparatif pengkaji gunakan dalam menganalisis perbandingan pandangan tentang kedudukan turath yang ada pada ulama dengan kefahaman yang ada di dayah Aceh. 
menginginkan pendapat mereka diwarisi dan dipedomani kemudiannya sepertimana umat berpedoman kepada al-Qur'an dan hadith.

Abū Isḥāq al-Shāṭibī menyebutkan, para sahabat Rasulullah SAW telah bersepakat untuk mengumpulkan al-Qur'an dan membukukannya dalam beberapa mushaf kemudian menyatukan umat dalam Mushaf 'Uthmānī sahaja dan meninggalkan yang selain itu. Kemudian tradisi yang baik ini diikuti oleh generasi selepas mereka, lalu mereka pula mengumpulkan semua ilmu pengetahuan dan membukukannya sepertimana yang dilakukan oleh Malik r.a. Manakala ulama sebelumnya tidak menyukai pembukuan hadith dan ilmu lainnya. Hal ini dapat difahami kerana mereka risau umat akan berpada dengan buku dan tidak lagi menghafaz dan berijtihad, dan boleh jadi pula mereka tidak menyukai pembukuan ilmu yang berasaskan ijtihad bukan yang berasaskan riwayat daripada al-Qur'an dan hadith. Namun begitu, ketika pengetahuan umat semakin lemah, bilangan para ulama yang berijtihad semakin sedikit, ditambah lagi dengan kerisauan terhadap pupusnya ilmu agama, maka para ulama kemudiannya bersepakat untuk membukukan semuanya. ${ }^{18}$

Al-Lakhamī, setelah mendedahkan pendapat Malik dan perbezaan pendapat para ulama dalam hal tidak menyukai penjualan buku yang berkaitan ilmu pengetahuan, menyatakan:

"Aku tidak melihat kebolehan penjualan kitab-kitab ilmu pengetahuan sebagai suatu perkara yang patut diperselisihkan pada zaman sekarang ini. Terutamanya ketika hafazan dan kefahaman umat tentang agama semakin lemah, ditambah lagi ulama terdahulu tidak banyak menulis kitab untuk dapat dibaca oleh penerus selepas mereka". ${ }^{19}$

Ia meriwayatkan, Malik r.a berkata:

"Al-Qāsim dan Sa'īd tidak menulis kitab. Aku tiada menulis dalam kitab Muwatța ' yang berasaskan riwayat daripada kitab ulama sebelumnya. Aku bertanya kepada Ibn Shihāb: Adakah engkau menulis kitab? Ia menjawab: Tidak. Aku bertanya

18 Abū Isḥāq Ibrāhīm Ibn Mūsā al-Shāțịīi, al-I'tiṣām (Kaherah: Dār al-Ḥadīth, 2003), 1:129.

19 Al-Shāṭibīi, al-I'tiṣām, 1:129. 
lagi: Adakah engkau menyukai jika orang lain menyandarkan pendapat kepadamu? Ia menjawab: Tidak suka". ${ }^{20}$

Al-Lakhami melanjutkan, demikianlah tradisi keilmuan dalam kalangan ulama pada masa itu. Andai perkara itu diterapkan di masa kini, maka sungguh ilmu pengetahuan akan menjadi pupus. ${ }^{21}$

Ibn al-Qayyīm menyebutkan, para Imam mazhab melarang umat mengikuti mereka dan mencela orang mengikuti pendapat mereka jika tidak berasaskan dalil. Al-Shāfi' $\overline{1}$ sendiri mengumpamakan orang yang mengamalkan suatu pendapat tanpa wujud dalil sebagai seorang pencari kayu bakar pada malam hari yang mengikat tumpukan kayunya. Terkadang dalam ikatan itu terdapat ular yang dapat mengigitnya tanpa ia sedar. ${ }^{22}$ Ismā'îl Ibn Yaḥyā al-Muzānī dalam kitab Mukhtașar menyebutkan: Aku menyebutkan dalam kitab ini ringkasan daripada fikah al-Shāfi'‘ dan pernyataan-pernyataannya, agar dapat ku sampaikan kepada sesiapa jua yang menginginkannya. Sekalipun āl-Shafi'ī sendiri telah memaklumkan larangan ber-taqlid kepadanya dan kepada ulama selain beliau. ${ }^{23}$ Abū Hanīfah melarang para pengikut mazhab mengamalkan pendapatnya, sehinggalah mereka mengetahui dalil yang beliau pedomani. Dalam riwayat lainnya beliau menyatakan:

"Siapapun tidak boleh berfatwa dengan pendapatku, sehinggalah ia mengetahui dalil yang aku pedomani. Sesungguhnya kami ini adalah manusia, yang boleh jadi pada suatu hari kami mengamalkan satu pendapat, tetapi di lain hari kami akan merubahnya". ${ }^{24}$

Ibn al-Qayyīm menyatakan, kita tidak mengatakan bahawa Allah mewajibkan setiap hamba untuk berijtihad sendiri dalam semua perkara. Tetapi sesuatu yang tidak dapat diterima, ini juga ditolak oleh genarasi sahabat dan tabi in, adalah perkara yang

20 Al-Shātịīî, al-I'tișām, 1:129.

21 Al-Shātịib̄, al-I'tișām, 1:129.

22 Ibn al-Qayyīm al-Jawziyyah, I'lam al-Muwaqqi'īn 'an Rabb al-'Āamīn (Kaherah: Dār al-Hadīth, 2004), 2:447.

23 Ibn al-Qayyīm, I 'lam al-Muwaqqi 'ìn 'an Rabb al-'Ālamīn, 2:447. Ismā‘̄ill Ibn Yahyā Ibn Ismā'il al-Muzānī, Mukhtașar al-Muzān̄̄ fì Furū' alShāfi 'iyyah (ed. 1, Beirut: Dār al-Kutub al-'Ilmiyyah, 1998), 1:7.

24 Muhammad Nāșir al-Dīn al-Albān̄̄, al-Hadīth Hujjah bi Nafsihi fī al'Aqā'id wa al-Ahkām (Riyadh: Maktabah al-Ma'ārif wa al-Nashr, 2005), 75. 
telah berlaku pada abad ke-4 hijrah. Iaitu berbangkitnya kecenderungan umat untuk mentabalkan seorang ulama dan menjadikan pendapatnya berkedudukan seperti Nușūs al-Shāri ${ }^{25}$ Manakala yang menjadi amalan sepatutnya dalam agama adalah mengikuti dan lebih mengutamakan nas daripada pendapat para ulama, juga menjadikan al-Qur'an dan hadith sebagai pedoman dalam menyelesaikan perselisihan. ${ }^{26}$ Hal ini sesuai dengan pernyataan al-Shāfi' ${ }^{1}$ bahawa sesiapa sahaja yang telah menemukan hadith Nabi, maka ia tidak boleh berpaling ke pendapat yang bercanggah dengan hadith. Dalam riwayat yang sahih pula al-Shāfi'ī mengatakan bahwa apabila telah terdapat hadith yang sahịh, maka hendaklah orang membuang pendapatnya ke dinding. ${ }^{27}$

Sebagai bukti bahawa perkara ini telahpun wujud, Ibn alQayyī̄m sendiri dalam kitab I'lam al-Muwaqqi'in telah mengumpulkan sebanyak 73 (tujuh puluh tiga) contoh permasalahan yang telah menjadi amalan para pengikut mazhab yang bercanggah dengan hadith șahịh. ${ }^{28}$ Al-Fulānī dalam kitab Iqaz al-Himam sepertimana yang dinukilkan oleh al-Albānī menyebutkan, Ibn Daqīq al-' $\bar{I} d$ dalam sebuah karya besarnya telah membuat perbincangan pada pelbagai permasalahan yang telah menjadi amalan dalam mazhab empat, sama ada perorangan mahupun jumhur, yang bercanggah dengan hadith sahīh. Sehinggalah beliau menyatakan, menyematkan pendapat-pendapat seperti itu kepada para imam mazhab adalah haram hukumnya. Untuk berhindar daripada berbuat kebohongan kepada para imam mazhab, maka para pengikut wajib mengetahui perkara-perkara tersebut agar tidak menyandarkannya kepada mereka. ${ }^{29}$

25 Ibn al-Qayyīm al-Jawziyyah, I'lam al-Muwaqqi 'inn, 492; Lihat al-Albānī, alHadith Hujjah bi Nafsih, 78-79.

26 Ibn al-Qayyīm, I'lam al-Muwaqqi 'in, 496.

27 Ibn al-Qayyīm, I'lam al-Muwaqqi 'īn, 507.

28 Al-Albānī, al-Hadith Hujjah bi Nafsihi, 90.

29 Al-Albānī, al-Hadith Hujjah bi Nafsihi, 90. 


\section{Kedudukan Kitab Turāth dalam Pandangan Ulama Zaman Moden}

Menyingkapi amalan sebahagian pengikut mazhab yang menjadikan kitab turāth sebagai rujukan yang sebanding dengan al-Qur'an dan hadith, al-Qarḍāwī menjelaskan bahawa ketika yang ma'sum hanya Rasulullah S.A.W dan selain beliau adalah manusia yang boleh benar dan salah, maka mengkaji semula semua pendapat para ulama yang terdapat dalam kitab turāth adalah suatu kewajiban bagi generasi setelahnya. Agar dapat dikenalpasti tingkat kebenarannya berdasarkan al-Qur'an dan hadith yang sahịh, dan pendapat-pendapat apa jua yang tidak bersuaian dengan keduanya. Sama ada diakibatkan oleh kekurangan yang ada pada setiap manusia mahupun dipengaruhi oleh alam sekitar. Dengan begitu, sentiasa ada perbezaan antara yang menjadi dasar ilahi dan basharī, antara yang berkekalan tiada pernah berubah (thābit) dengan yang sentiasa berubah-berubah (mutaghayyir), dan antara yang dapat diterima dengan yang wajib ditolak. ${ }^{30}$

Apabila pendapat apa jua yang datang daripada ulama salaf sahaja wajib diukur kebenarannya dengan al-Qur'an dan hadith, apatah lagi pendapat-pendapat yang bersumber daripada ulama khalaf. Dengan demikian dapat diketahui bahawa penilaian tingkat kebenaran terhadap pendapat apa jua yang bersumber daripada kitab turäth wajib diukur dengan timbangan Allah SWT dan Rasulullah SAW. Agar dapat diambil pendapat yang benar dan ditinggalkan pendapat yang salah, dan dapat memilih pendapat mana yang lebih baik untuk diamalkan. Sebagaimana Allah SWT telah menggambarkan tentang hambanya yang mendapatkan petunjuk dan berakal dalam firmannya:

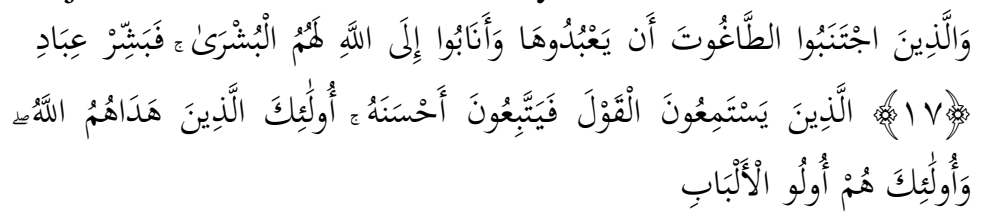

Al-Zumar 39: 17 dan 18

Terjemahan: Orang-orang yang sentiasa menghindari menyembah țăghūt dan sentiasa kembali kepada Allah, bagi

30 Yūsuf al-Qarḍāwī, Kayfa nata 'āmal ma'a al-Turāth wa al-Tamadhdhub wa al-Ikhtilaf, ed. ke-2 (Kaherah: Maktabah Wahbah, 2004), 33. 
mereka adalah khabar gembira, maka berilah khabar gembira kepada hambaKu. Iaitu mereka yang mendengarkan pendapat lalu mengambil yang terbaik. Mereka adalah orang-orang yang diberikan petunjuk oleh Allah, dan merekalah orang yang memiliki hati.

Mereka yang digambarkan oleh Allah SWT sebagai orangorang mempunyai akal adalah yang tidak mengikuti yang baik sahaja, tetapi mereka berupaya mengikuti yang lebih baik juga. ${ }^{31}$

Jika yang telah menjadi suatu ketetapan bahawa kitab turāth adalah merupakan hasil produk ulama yang tidak mempunyai sebarang jaminan tidak salah ( 'iṣmah) dan tidak juga mempunyai sebarang kesucian (qadāsah), maka merupakan hak sesiapa jua untuk bersikap kritis terhadap khazanah yang kaya ini agar dapat diambil faedah daripadanya. Iaitu dengan cara mengkaji dan memilih yang dapat diterima oleh dalil aqli dan tidak bercanggah pula dengan dalil naqli, bersesuaian dengan kemaslahatan umat, meninggalkan yang dapat dipastikan kesalahannya atau tiada lagi bersesuaian untuk diterapkan di zaman kini. ${ }^{32}$

Dalam memilih pendapat mazhab yang lebih tepat untuk diterapkan pada zaman kini al-Qarḍāwī menjelaskan, perbahasan semula terhadap kandungan kitab fikah klasik (turāth) dan memilih pendapat tertentu yang terdapat di dalam mazhab untuk diamalkan di zaman kini tidak bermakna kita boleh memilihnya sembarangan, atau mengikuti keinginan orang ramai atau golongan tertentu. Iaitu dengan mencari-cari pendapat yang ringan (Tatabbu'al-Rukhas) dalam mazhab, atau mencari-cari kesalahan para ulama, lalu meninggalkan pendapat-pendapat yang disokong oleh hadith atau athār. Sesungguhnya hukum-hukum yang

31 Al-Qarḍāwī, Kayfa Nata 'āmal ma'a al-Turāth wa al-Tamadhdhub wa alIkhtilaf, 33.

32 Al-Qarḍ̄īī, Kayfa nata 'āmal ma'a al-Turāth wa al-Tamadhdhub wa alIkhtilaf, 41; Dalam kitab Taysīr al-Fiqh li al-Muslim al-Muā'sir fì Daw'i alQur'ān wa al-Sunnah al-Qarḍāwī juga dengan jelas menyatakan bahawa suatu hal yang wajib dipertegas adalah bahawa tiada satu pun pendapat para ulama yang terbebas daripada kesalahan kecuali yang bersumber daripada al-Qur'an dan hadith sahaja. Manakala selain daripada keduanya boleh diterima dan boleh juga ditolak. Lihat Yūsuf al-Qarḍāwī, Taysīr al-Fiqh li al-Muslim al-Muā'sir fi Daw'i al-Qur'an wa al-Sunnah (ed. ke-3, Kaherah: Maktabah Wahbah, 2004), 151. 
dikandungi oleh kitab turāth juga berbeza-beza tingkatan sumbernya. Ada di antara hukum yang bersumber nas al-Qur'an dan hadith, ada pula sebahagiannya berasaskan ijma', qiyās, istiḩsān, maslahah, atau 'urf atau sumber-sumber lain yang diperselisihkan di kalangan para ulama. ${ }^{33}$

Hukum yang bersumber daripada nas juga tidak berada pada satu tingkatan. Sebahagiannya berstatus saḥ̄h al-thubüt (kuat) dan șarịh al-dalālah (jelas makna), sebahagiannya lagi berstatus șahīh tapi ghayr șarīh atau șarīh tapi ghayr șahịh. Demikian pula dengan hukum yang berasaskan ijm $\bar{a}$. Kerana ia adakalanya bersumber daripada sahabat dan ada juga ijm $\bar{a}^{\prime}$ yang bersumber daripada generasi setelah mereka. Ada ijmá ' berbentuk qawli dan ada pula yang berbentuk sukuțī, bahkan ada juga di antara ijma tersebut sememangnya tiada asal, meskipun ada terkadang juga sebuah ijmáa 'yang dibina atas suatu kemaslahatan sementara yang sudah tiada lagi berlaku di zaman kini, ataupun dibina atas suatu 'urf yang ianya telahpun pupus. Oleh itu, semua permasalahan, pendapat dan sumbernya wajib dikaji secara terpisah. Iaitu dengan cara menyesuaikan dengan al-Qur'an dan hadith bagi menghasilkan kefahaman yang benar. ${ }^{34}$

Bakr Zak̄̄ 'Iwād menyebutkan, di antara tanda-tanda daripada upaya men-taqdis-kan turäth adalah memposisikan matan-matan kitab turāth itu sendiri sebagai nas agama. Kehadiran mazhabmazhab fikah yang sepatutnya menjadi kekayaan pendapat yang dapat memudahkan umat dalam hal ibadah dan pelbagai aktiviti kehidupan lainnya telah disalahertikan oleh para pengikutnya, sehinggalah ianya menjadi tempat bagi mewujudkan taksub. Para ulama tentu sangat mengetahui bahawa tiada sesiapapun dari kalangan imam mazhab yang mengajak orang lain untuk mengikuti pendapat mereka. Bahkan semua imam mazhab melarang orang lain mengikuti pendapat mereka selama tiada mengetahui dalil yang mereka pedomani. Di antara mereka ada yang mengatakan: pendapatku benar, namun boleh juga menjadi salah. Ada pula yang membuat pernyataan: Ini adalah pendapat

33 Yūsuf al-Qarḍāwī, Shari 'ah al-Islām Șalihah li al-Taṭbiq fĩ Kullī Zamān wa Makān (ed. ke-5, Kaherah: Maktabah Wahbah, 1997), 79.

34 Al-Qarḍāwī, Shari'ah al-Islām Șaliḥah li al-Tațbiq fì Kullī Zamān wa Makān, 79. 
yang sanggup kami fikirkan, maka sesiapa yang mampu berpendapat yang lebih baik dari pendapat kami hendaklah ia mengikuti pendapatnya. ${ }^{35}$

Semua para imam mazhab juga mengatakan: Jika suatu hadith itu sahịh dan dapat diamalkan, maka itulah mazhabku. Semua imam mazhab saling menghormati dan menghargai pendapat imam yang lain. Bahkan terkadang juga mereka mengikuti pendapat imam tertentu di suatu tempat dan meninggalkan pendapatnya sendiri kerana ingin menghormati dan menghargai pendapat imam tersebut. Namun sangat disayangkan, kepelbagaian pendapat dalam memahami nas di dalam mazhab fikah kemudian berubah menjadi agama yang wajib diikuti. Oleh itu, gejala taksub sentiasa wujudnya lebih kuat dan berat ketika seseorang tidak mendalam pada perbahasannya. Betapa banyak didapati para pendakwah yang menyalahkan pendakwah lain hanya kerana kekurangan ilmu ataupun disebabkan oleh rasa taksub terhadap pendapat mazhabnya. Orang yang memiliki keluasan ilmu akan sentiasa mengambil daripada pendapat para fuqahak apa jua yang bersesuaian dengan keadaan si penanya. Jika ada seseorang yang teringin melakukan solat Jumaat akan tetapi ia hanya sempat mengikuti imam solat pada waktu tashahhud, maka tentu akan lebih baik menyuruhnya untuk mengikuti mazhab Abū Ḥaniīfah sahaja dengan cara menyempurnakan solatnya hanya dengan menambah dua raka'at, daripada akan memberatkannya dengan menyuruh menyempurnakan empat raka'at Zohor berdasarkan mazhab al-Shāfi ${ }^{\prime} \overline{1}^{36}$

Bakr Zakī 'Iwāḍ menambahkan, para ulama yang sangat mengetahui tentang pendapat-pendapat para imam mazhab adalah murid-murid mereka sendiri. Seandainya pendapat para imam mazhab itu berperingkat seperti nas al-Qur'an dan hadith sungguh mereka tiada pernah membuat pendapat yang bercanggah dengan pendapat Imam. Para ulama murid Abū Ḥan̄fah memiliki pendapat tersendiri dalam hal tertentu sehingga terdapat pernyataan: pendapat Abū Hanīfah begini, sedangkan pendapat kedua muridnya Abū Yūsuf dan Muhammad Ibn al-Ḥasan alShaybān̄̄ begini. Ulama pengikut al-Shāfi'‘̄ pula seperti al-

\footnotetext{
35 Bakr Zakī 'Iwāḍ, al-Turāth al-Islāmī, 67.

36 Bakr Zakī 'Iwāḍ, al-Turāth al-Istāmī, 68.
} 
Muzān̄̄, al-Nawāwīe al-Rafi‘'î dan lainnya memiliki pendapat tersendiri dalam hal tertentu. Jika pendapat al-Shāfi ‘'i adalah seperti nas al-Qur'an dan hadith sungguh para pengikut tiada akan menyalahinya. ${ }^{3}$

Kehadiran kitab-kitab fikah klasik (turāth) sebagai suatu kekayaan khazanah umat Islam juga tidak luput daripada pemerhatian Bakr Zaki 'Iwad. Dalam hal ini ia menyatakan: Kitab-kitab klasik yang terdapat dalam fikah mazhab dapat menjadi sebagai dampak positif, sebagaimana ianya juga dapat menjadi dampak negatif. Dampak positif dapat wujud pada terbukanya kesempatan memilih di antara pendapat-pendapat yang tersedia yang bersesuaian dengan keadaan orang yang bertanya. Hal ini sesuai dengan hadith 'A'ishah, iaitu:

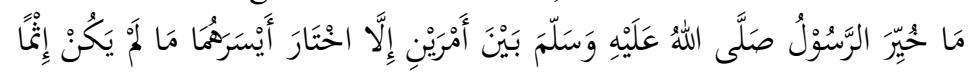

Terjemahan: Sesungguhnya Rasulullah SAW setiap berdepan dengan dua perkara, pastilah baginda memilih yang lebih mudah diantara keduanya, selama perkara itu bukan sebuah dosa. $^{38}$

Juga sesuai dengan hadith Rasulullah SAW pada hari nahr dalam Hajj al-Wada' kepada para jemaah yang tidak menjaga tertib yang bersesuaian dengan amalan beliau, baginda berkata: if'al wala haraj (berbuatlah, tiada yang menjadi sebuah kesusahan). Berdasarkan hal ini, maka terselesailah masalah umat jika beramal dengan pendapat fikah Ja'far al-Ṣādiq, Ibn Ḥazm alAndalūsī, al-Layth Ibn Sa'ad al-Mișrīe al-Awza'ī dan banyak lagi.

Bakr Zakī 'Iwāẹ, al-Turāth al-Islāmī, 69.

Hadith riayat al-Bukhārī, Kitab al-Ḥudūd, Bāb Iqāmat al-Ḥudūd wa alIntiqām li Hurmat Allāh, no. Hadith 6788. Lihat Muhammad Ibn Ismā‘îl alBukhārī, Al-Jāmi ‘ al-Ṣahīh (edisi pertama, Jeddah: Dār Ṭ̂̄q al-Najah, 2001), 8:160. Hadith riwayat Muslim, Kitāb al-Faḍā'il, Bāb Muba'adatuhu Șalla Allāh alayhi wa sallam li al-Atham wa Ikhtiyaruhu min al-Mubāh Ashalahu wa Intiqamuhu li Allah 'inda Intihak Hurmatihi, no. Hadith 2327. Lihat Muslim ibn al-Hajjāj ibn Muslim ibn Ward, Al-Ṣahịh (Beirut: Ihyā' alTurāth al-'Arabī, t.t.), 4:1813; Lihat juga hadith riwayat al-Bukhārī, Bab Husn al-Khuluq, no. Hadith 274. Lihat Muhammad bin Ismā‘īl al-Bukhārī, “al-Adāb al-Mufrad," dalam Șahīh al-Ādāb al-Mufrad, Muḥammad Nāṣir al-Dīn al-Albān̄i, Bab Sakhawat al-Nafs, no. Hadith 208/274 (ed. ke-4, t.tp.: Dār al-Ṣiddīq, 1997), 1:119. 
Manakala dampak negatif yang dibangkitkan oleh fikah mazhab adalah apabila pengikut sesuatu mazhab mempunyai pandangan bahawa hanya pendapat mazhab yang diikuti sahaja yang benar, selain itu semuanya salah. Atau mengharamkan mentaqlid imam mazhab lain selain imam yang diikuti dengan mengetengahkan kes talfiq, kes siapa yang lebih berhak untuk menjadi imam solat, yang bermazhab al-Shāfi' $\overline{1}$ kah atau yang bermazhab al-Hanafi, adakah seorang yang bermazhab al-Shafi' $i$ wajib melakukan solat semula jika ia tahu yang menjadi imam adalah seorang yang bermazhab al-Hanafī, ditambah lagi dengan adanya upaya melemparkan penghinaan dalam media untuk menjatuhkan satu mazhab dan membela mazhab lain. ${ }^{39}$ Bakr Zakī 'Iwāọ menambahkan, aku sentiasa mengatakan sama ada kepada jemaah solat ketika berada di atas mimbar mahupun kepada mahasiswa di universiti: Ajaklah orang ramai untuk melakukan solat, dan katakan kepada mereka bahawa Allah SWT memerintahkan kalian untuk melakukan solat, dan kalian tiada pernah ditanya dengan mazhab mana kalian melaksanakannya. Suruhlah mereka berpuasa, membayar zakat, dan berhaji tanpa perlu membabitkan mereka dengan mazhab tertentu. Kerana pemikiran bermazhab pada asalnya tiada hubungkait dengan rukun Islam, ia berbangkit hanya untuk memudahkan pelaksanaan. Pelaksanaan suatu ibadah terkadang menuntut untuk berpindah dari suatu mazhab ke mazhab yang lain, jika hal itu tidak dilakukan maka umat akan mengalami kesusahan. Seperti tawaf orang yang tengah haid, nifas, atau melempar jamrah sebelum tergelincir matahari. Seperti yang didapati pada pendapat sebahagian ulama al-Malikiyyah bawaha sesiapa yang terlupa melakukan tawaf rukun atau ia tidak dapat melakukannya, maka sah hajinya jika ia telah melakukan Tawaf al-Qudum. Dalam perkara ini Bakr Zaki 'Iwad mencabar para ulama yang mengajak kepada taksub mazhab tertentu untuk memberikan satu nas yang sạīh sanad dan matan serta sarīh pula dalalah-nya yang menyatakan bahawa mengikuti mazhab tertentu hukumnya wajib. Bagi beliau aliran mazhab fikah adalah suatu fenomena baru yang 
berbangkit 150 (seratus lima puluh) tahun selepas wafat Rasulullah SAW ${ }^{40}$

Demikianlah gambaran berkenaan pandangan para ulama pakar dalam Islam. Iaitu dimulakan daripada enggan menulis selain al-Qur'an dan hadith, kerana ditakutkan akan melalaikan umat daripada merujuk kepada al-Qur'an dan hadith, dan dikhawatirkan pula umat akan menjadikan pendapat para ulama berkedudukan satu peringkat dengan Nușūṣ al-Shāri'. Sehinggalah sampai masa semuanya dituliskan, kerana dikhawatirkan ilmu akan menjadi pupus. Dalam pada itu, para ulama yang mengajak kepada islah dari pelbagai kalangan dan di pelbagai masa sentiasa mempertegas bahawa apa jua yang telah termaktub dalam kitab turāth adalah hasil kefahaman para ulama tentang shari'at yang dapat berubah-ubah dan tidak bersifat ma sum daripada kesalahan dan kekeliruan. Manakala shari'at yang sebenar wujud dalam alQur'an dan hadith. Oleh itu, segala apa jua yang termaktub dalam kitab turāth wajib diukur kebenarannya berasaskan kedua sumber ini.

\section{Analisis Pentakdisan Kitab Turāth dalam Pandangan Ulama Dayah Tradisional Aceh}

Kajian ini difokuskan pada apa yang diterapkan oleh kalangan dayah tradisional dalam melakukan pengajian, memilih hadith sebagai pedoman dalam meng-istinbat hukum, dan menjadikan kesimpulan hukum yang diambil dengan cara begitu sebagai kesimpulan final daripada sebuah kebenaran. Fenomena pentakdisan kitab turāth sangat tampak jelas sekali wujud pada pandangan kalangan dayah tradisional dalam pengajian fikah dan mengketepikan pengajian hadith.

Secara am pengajian hadith di dayah tradisional hanyalah sebagai pelengkap kurikulum sahaja. Kitab-kitab hadith yang dijadikan pegangan juga mengikuti kepada tradisi yang telah dipedomani dan dibaca oleh para guru-guru terdahulu. Pengajian hadith di dayah tradisional adalah lebih kepada sekadar pembacaan hadith secara zahir sahaja. Dengan kata lain dapat dikatakan bahawa pengajian hadith yang terdapat dalam 
kurikulum dayah tradisional hanya untuk mencari pengetahuan zahir nas dan mencari keberkatan daripada pembacaan dan pengajian hadith. ${ }^{41}$ Manakala pengajian hadith yang dimaksudkan untuk memperkuat sumber pengetahuan dan dalil hukum sangatlah tidak tampak dalam pengajian hadith di dayah tradisional.

Kalangan dayah tradisional mempunyai keyakinan bahawa dalam mengamalkan dalil cukup hanya merujuk kepada kitab fikah. Kerana apa yang telah wujud dalam kitab fikah adalah merupakan hasil syarahan ulama daripada hadith, dan perkara ini lebih benar daripada mengikuti penjelasan yang didedahkan dalam syarahan hadith. Oleh itu, mereka tidak perlu melihat hadith untuk memperkuat suatu permasalahan fikah, dan matan kitab yang dijadikan sebagai pegangan dan pedoman adalah mewakili hadith. Mereka merasa tidak layak untuk mencari hukum daripada hadith, kerana yang wujud dalam kitab fikah pun belum habis dikaji. ${ }^{42}$ Kefahaman seperti ini sudah menjadi amalan yang wujud dalam semua kalangan dayah tradisional di Aceh, dan mereka sangat berhati-hati dalam menggunakan hadith. Oleh itu jika mendengarkan perbahasan fikah yang didedahkan oleh orang dayah tradisional, maka sangat jarang didapati yang merujuk kepada hadith, dan mereka hanya memadai dengan menyebutkan matan kitab sahaja. ${ }^{43}$

Di dalam tradisi dayah, pendapat ulama golongan alShāfi'iyyah yang paling kuat adalah pendapat al-Nawāwī. Manakala terjadi percanggahan antara Imam al-Nawawi dengan Imam Rafi' ${ }^{\wedge}$, maka dalam perkara ini yang didahulukan adalah

41 Ajidar Matsyah (Alumni Dayah Tanoh Mirah Aceh Utara, Pensyarah di Jabatan Sejarah Kebudayaan Islam, Fakulti Adab, Universiti Islam Negeri Ar-Raniry), dalam temu bual dengan pengkaji, 5 April 2018; Maklumat yang sama juga didapati dari FZ (Guru Senior pada Lajnah Bahsul Masail, Dayah Mudi Mesra Samalanga), dalam temu bual dengan pengkaji, 21 Januari 2018.

42 IM (Guru Senior pada Lajnah Bahsul Masail, Dayah Mudi Mesra Samalanga), dalam temubual dengan pengkaji, 21 Januari 2018; STM (Guru Senior Dayah Mudi Mesra Samalanga), dalam temu bual dengan pengkaji, 21 Januari 2018.

43 Ajidar Matsyah (Alumni Dayah Tanoh Mirah Aceh Utara, Pensyarah di Jabatan Sejarah Kebudayaan Islam, Fakulti Adab, Universiti Islam Negeri Ar-Raniry), dalam temu bual dengan pengkaji, 5 April 2018. 
Imam al-Nawāwī. ${ }^{44}$ Oleh itu, untuk melihat kebenaran suatu persoalan fikah, maka mereka merujuk kepada kitab al-Majmu“ karya al-Nawāwī, walaupun kitab ini tidak terdapat dalam kurikulum utama pendidikan dayah tradisional. Kitab tersebut adalah sebagai rujukan apabila terdapat permasalahan yang diteroka oleh pimpinan-pimpinan dayah tradisional. Manakala para pelajar di tingkatan enam ke bawah tidak mempelajari kitab ini. Namun begitu, tidak tertutup kemungkinan pula ada di kalangan pelajar yang telah mampu membaca kitab Tuhfah alMuhtaj dan bahkan juga kitab al-Majmū'. Jika hal itu berlaku, maka ianya akan tampil sangat mulia di kalangan teman-temannya setiap kali ia tampak memegang kitab tersebut dan ketika menghadap para guru senior. Namun yang sangat perlu dikutip di sini adalah kalangan dayah tradisional justeru menempatkan matan-matan kitab turāth terutamanya kitab seperti Tuhfah dan alMajm $\bar{u}^{\prime}$ di peringkat yang berkekuatan sama dengan peringkat hadith. Dengan alasan bahawa para ulama telah mensyarahinya dan itu adalah hasil interpretasi mereka daripada hadith. Menurut kalangan dayah tradisional, al-Shāfi'i mahupun al-Nawāwī telah menggunakan hadith dalam menyelesaikan persoalan. Oleh itu, para pengikut mazhab tiada perlu lagi merujuk kepada hadith sebagai sumber. ${ }^{45}$

Kenyataan ini telah membuat dan mewujudkan pedoman yang berbanding terbalik dengan apa yang diajarkan oleh kebanyakan para ulama salaf. Kitab-kitab turāth tersebut yang sepatutnya menjadi sarana (wasilah) untuk mencapai kefahaman, tetapi ianya telah menjadi tujuan (ghayah) untuk mengukur suatu kebenaran. Sepatutnya yang difahami dari matan-matan kitab

44 SJ (Alumni Dayah Mudi Mesra Samalanga, Pensyarah di Universiti Islam Negeri Ar-Raniry, Banda Aceh), dalam temu bual dengan pengkaji, 15 Ogos 2018

45 Ajidar Matsyah (Alumni Dayah Tanoh Mirah Aceh Utara, Pensyarah di Jabatan Sejarah Kebudayaan Islam, Fakulti Adab, Universiti Islam Negeri Ar-Raniry), dalam temu bual dengan pengkaji, 5 April 2018; Hal serupa pula pengkaji dapati ketika melakukan temu bual dengan NSH (Guru Senior di Peringkat Tujuh pada Pelajar Putri, Dayah Mudi Mesra Samalanga), dalam temu bual dengan pengkaji, 21 Januari 2018; Juga dari FZ (Guru Senior pada Lajnah Bahsul Masail, Dayah Mudi Mesra Samalanga), dalam temu bual dengan pengkaji, 21 Januari 2018. 
tersebut adalah salah satu kefahaman dari para pakar terhadap suatu persoalan fikah dengan dalil hadith yang dipedomani. Namun lebih dari itu, matan-matan kitab itu pula akhirnya telah berkedudukan seperti hadith. Sikap yang telah turun temurun diwarisi oleh para pelajar atau guru, pada gilirannya telah membuat mereka terperangkap dalam sikap men-taqdis-kan kitab turāth, bukan lagi sikap mentakdirkannya (menghargai). ${ }^{46}$

Ini adalah sebuah fenomena yang berlaku di masa taksub mazhab berbangkit sejak pertengahan abad ke-4 hijrah. Menggambarkan tentang hal ini alSayyīd Sābiq mengatakan bahawa umat Islam selepas zaman salaf telah tiada minat lagi untuk berijtihad sepertimana generasi sebelumnya, bahkan berbangkit semangat ber-taqlid. Sejak itu para pengikut mazhab mengurung diri dan hanya berpedoman pada mazhab yang diikuti, bertaksub dan bertungkus lumus dalam membela mazhabnya. Pendapat imam mazhab dipandang berkedudukan seperti Naș al-Shārī', dan tiada akan pernah memberikan fatwa yang bercanggah dengan pendapat imam. Sikap ghuluww dalam memberikan kepercayaan kepada para imam mazhab hingga ke tahap meyakini bahawa setiap ayat al-Qur'an atau hadith yang bercanggah dengan pendapat mazhab, maka makna ayat atau hadith tersebut wajib di-ta'wil-kan ataupun meyakini bahawa ayat atau hadith tersebut telah dimansukhkan, sepertimana yang dikengahkan oleh Imam al-Karkhi. Upaya ber-taqlid dan sikap taksub inilah kemudiannya semakin menjauhkan umat daripada berpedoman kepada al-Qur'an dan hadith dan berbangkit pula isu pintu ijtihad telah tertutup. Akhinya, pendapat para fuqaha' dipandang sebagai shari'at, dan shari'at adalah wujud dalam pendapat para fuqahak. Sesiapa sahaja di antara para ulama yang berpandangan bercanggah dengan pendapat para fuqahak yang wujud dalam mazhab, maka ia akan dianggap sebagai seorang mubtadi ' yang tidak dapat diterima pendapat dan fatwanya. Lihat alSayȳ̄d Sābiq, Fiqh al-Sunnah (ed. ke-21, Kaherah: Dār al-Fatḥ li al-I'lam al-'Arābī, 1999), 1:8; Lihat juga al-Hasan al-'Alamī, Tajdīd al-Fikr alIslāmī (ed. pertama, Kaherah: Maktabah al-Turāth al-Islāmī, 2003), 131132; Al-Albānī dalam perkara ini juga menyebutkan, sekalipun kita wajib menghormati dan menghargai bahkan wajib ber-taqlid kepada para ulama mazhab ketika mereka mendedahkan dalil, namun begitu ianya tidak bermakna bahawa kita meletakkan pendapat mereka pada peringkat di atas peringkat hadith, dan tidak pula kita lebih mendahulukan pendapat imam mazhab daripada hadith. Lihat Muhạmmad Nāṣir al-Dīn al-Albān̄i, alTasfiyyah wa al-Tarbiyyah wa Hajah al-Muslimīn ilayhā (ed. pertama, Riyadh: Maktabah al-Ma'ārif wa al-Tawzī', 2007), 23; Baca juga al-Shāțibī, al-I'tișām, 2: 535; Baca juga 'Umar Sulaymān al-Ashqār, Tarīkh al-Fiqh alIslāmī, ed. ke-3 (Jordan: Dār al-Nafā' is, 2003), 116; Baca juga Muhammad Ibn al-Hasan al-Hajawī, al-Fikr al-Sami fì Tarīkh al-Fiqh al-Islāmī (Beirut: al-Maktabah al-'Așriyyah, 2012), 2: 369. 
Pernyataan yang sentiasa diperdengarkan setiap kali mempertanyakan tentang apa jua yang telah termaktub di dalam kitab turāth adalah bahawa yang di dalam kitab turāth itu semuanya benar, dan ulama tidak mungkin mendedahkannya di dalam kitab mereka jika hal itu tidak benar. Pernyataan ini tentu akan sangat bercanggah dengan apa yang telah dilakukan oleh para ulama ketika mereka merasa perlu mentahkikkan makhțțtah (manuskrip) sebelum didedahkan untuk dicetak. Ditambah lagi yang paling sangat berbahaya adalah ketika sikap tersebut diterapkan kepada hadith. ${ }^{47}$

Dalam pandangan am kalangan dayah tradisional, setiap hadith yang telah disebutkan di dalam kitab turāth semuanya dapat diamalkan dan tiada perlu dibuat kajian takhrīj lagi. Kerana jika hadith tersebut da if dan tidak dapat diamalkan, maka sungguh para ulama pengarang kitab tiada akan menyebutkannya di dalam kitab mereka. ${ }^{48}$

47 Ini adalah di antara amalan yang ditegah oleh al-Qaradawi dalam kitab alMarji 'iyyah al-'Ulya fì al-Islām li al-Qur'ān wa al-Sunnah. Ia menyebutkan, di antara amalan yang wajib ditolak adalah keengganan pengikut suatu mazhab untuk merujuk kepada al-Qur'an dan hadith. Mereka hanya berpada dengan pendapat para ulama mazhab yang diikuti dan menjadikannya seperti shari'at dan tiada mengambil kira terhadap perubahan kehidupan yang berlaku. Kelompok ini juga sentiasa menjadikan kefahaman dan praktikal para ulama, yang boleh menjadi benar dan salah, sebagai ajaran Islam seutuhnya. Mereka meyakini bahawa pernyataan dan pendapat apa jua yang dikandungi oleh kitab-kitab turath, demikian juga semua kehancuran dan kesalahan yang wujud dalam sejarah umat adalah sebagai bentuk daripada ajaran Islam. Lihat al-Qarḍāwī, al-Marji iyyah al'Ulyā fì al-Islām li al-Qur'ān wa al-Sunnah (ed. ke-2, Kaherah: Maktabah Wahbah, 2001), 17.

48 Ajidar Matsyah (Alumni Dayah Tanoh Mirah Aceh Utara, Pensyarah di Jabatan Sejarah Kebudayaan Islam, Fakulti Adab, Universiti Islam Negeri Ar-Raniry), dalam temu bual dengan pengkaji, 5 April 2018; Pada tahun 2000 pengkaji pernah ditugaskan oleh Prof. DR. Safwan Idris, MA selaku Rektor Instintut Agama Islam Negeri (IAIN) Ar-Raniry ketika itu untuk mengajar Bahasa Arab di salah satu dayah di Pantai Barat Aceh selama satu bulan penuh. Pada setiap malamnya ketika pengkaji tiada jadwal mengajar sentiasa ikut bersama para guru untuk mengaji kitab turath yang diajarkan oleh pimpinan tertinggi (Abu Dayah) sesuai dengan jadwal yang telah ditetapkan. Pada malam itu yang menjadi jadwal untuk dipelajari adalah kitab fikah andalan dayah, iaitu kitab Qalyūbī wa 'Umayrah yang oleh kalangan dayah disebut kitab al-Mahalli. Dalam suatu perbahasan di malam 
Gambaran seperti itu adalah sememangnya telah menjadi gejala am para pelajar dan ulama kalangan dayah tradisional. Rasa perlu dan semangat mereka untuk mengingat, menghafaz dan mengkaji hadith adalah jauh berada di bawah semangat mengingat dan menghafaz matan kitab-kitab tertentu. Bahkan jika ada yang berusaha membacakan hadith yang mungkin sahaja kandungan atau Fiqh al-Hadith yang berbeza dengan tradisi mereka, maka berkemungkinan besar yang bersangkutan akan tertuduh sebagai pembawa ajaran baharu, atau yang bersangkutan mungkin sahaja akan menjadi orang yang dicurigai membawa ajaran yang ingin mengganggu tradisi yang telah ada sebelumnya. ${ }^{49}$

Akibat kurangnya rujukan kitab dari kalangan ulama alShafi'iyyah yang dipelajari, fenomena ini juga telah membuat mereka tidak mengetahui adanya hadith atau dalil yang dijadikan pedoman dan pegangan oleh sebahagian kalangan ulama alShāfi'iyyah yang berlainan pendapat dalam sesuatu permasalahan fikah dengan apa yang pernah mereka pelajari. Oleh itu, pengkaji berpandangan bahawa mengekalkan kefahaman sepertimana yang mereka tempuh ini tidak akan dapat membantu para pelajar untuk mengenali pendapat-pendapat fikah di kalangan al-Shāfi'iyyah secara menyeluruh, apatah lagi untuk mengetahui pendapat dan hadith yang dijadikan sebagai dalil oleh ulama-ulama lain di luar

itu di dalam kitab tersebut termaktub pernyataan hadha hadithūn gharīb. Seketika para guru- dan Abu dayah selaku pengajar di majlis pengajian itu merasa tidak berpuas hati dengan pernyataan yang ada di dalam kitab. Kerana dalam kefahaman mereka dari kitab al-Bayqūn̄ yang mereka pelajari bahawa hadith gharib adalah hadith yang diriwayatkan oleh seorang perawi, dan jika hadith diriwayatkan oleh seorang perawi maka hadith tersebut dipandang tidak kuat. Di sini tampak para hadirin di dalam majlis pengajian itu kelam kabut berusaha membela matan kitab yang waktu itu kebetulan diperkuat dengan hadith gharìb. Kejadian ini adalah pengalaman langsung pengkaji yang dapat memberikan kesimpulan bahawa mereka belum berjaya memahami istilah hadith gharīb. Para pelajar senior yang juga telah menjadi dewan guru di dalam majlis waktu itu belum mampu membezakan antara pembahagian hadith ditinjau dari segi kuantiti dengan pembahagian hadith ditinjau dari segi kualiti. Sebenarnya tiada didapati sebarang masalah di dalam pernyataan itu seandainya mereka telah memahami dengan baik tentang pembahagian hadith ditinjau dari segi kuantiti dan kualiti.

49 SLM (Alumni salah satu dayah di Samalanga, Pimpinan salah satu dayah di Kabupaten Pidie), dalam temu bual dengan pengkaji, 10 Ogos 2018. 
kalangan al-Shāfi'iyyah. ${ }^{50}$ Seperti dalil pembolehan pembayaran zakat fitrah dengan nilai (wang) yang dipedomani oleh kalangan ulama al-Ahnaf yang diriwayatkan oleh al-Bukhārīi, ${ }^{51}$ Abū Bakar Ibn Abī Shaybah, ${ }^{52}$ al-Bayhāqī, ${ }^{53}$ dan disebutkan juga oleh Ibn Hajar al-'Asqalānī. ${ }^{54}$ Berikut adalah lafaz al-Bukhārī:

Perkara ini pernah ditegah oleh Abū Shamah sebagaimana dinukilkan oleh al-Diḥlāwī. Iaitu kepada sesiapa yang mendalami ilmu fikah maka hendaklah tidak hanya mempelajari satu mazhab sahaja. Melainkan ia wajib mempelajari pelbagai mazhab dan mengamalkan pendapat yang lebih dekat dan bersesuaian dengan al-Qur'an dan hadith. Juga wajib berhindar daripada bersikap taksub dan perselisihan pendapat, kerana Imam al-Shafi' $i$ sendiri dalam riwayat yang șahị melarang orang lain bertaklid kepadanya dan kepada selainnya. Lihat Aḥmad Ibn 'Abd al-Raḥ̄m Shah Waliy Allāh alDiḥlāwī, al-Insaffì Bayān Asbāb al-Ikhtilaf (ed. ke-8, Beirut: Dār al-Nafā' is, 1993), 100; Abū Isḥāq telah mempertegas bahawa suatu tindakan yang amat berbahaya jika seorang penuntut ilmu hanya berpada dengan fikah satu mazhab sahaja. Dalam perkara ini beliau mengatakan: Mengajarkan para penuntut ilmu hanya satu mazhab akan membuat mereka tidak menyukai dan menafikan pendapat mazhab lain. Kerana mereka tidak mengetahui dalil yang terdapat dalam mazhab di luar mazhabnya. Hal ini juga akan membuat para penuntut tidak menghargai kelebihan dan keunggulan imam mazhab lainnya, dan juga tidak akan mengetahui pengalaman dan kefahaman mereka dalam memahami maqāsid shar'iyyah. Lihat al-.Ashqār, Tarīkh al-Fiqh, 182. Al-Suyūṭ̄ dalam kitab Jazā'il al-Mawāhib fì Ikhtilāf al-Madhāhin sepertimana yang dinukilkan oleh Muhammad 'Awwāmah beliau menyatakan: Suatu perkara yang sangat pelik yang telah berlaku pada pengikut mazhab adalah mereka mengunggulkan suatu mazhab atas mazhab yang lain hingga ke tahap yang merendahkan imam mazhab yang ddikuti. Bahkan juga sehingga ke tahap berbuat taksub dan dendam jahiliyyah. Para imam mazhab tentu terbebas daripada semua kecelaruan ini. Lihat Muhammad 'Awwamah, Athār al-Hadīth al-Sharīf fì Ikhtilāf al-Ā'immah alFuqahā' (ed. ke-7, Jeddah: Dar al-Nashar li al-Tawzī', 2013), 28-29. Al-Bukhārī, al-Ṣaḥ̄ḥ, Kitab al-Zakah, Bab al-'Ard fī al-Zakāh, no. Hadith 1148, j.2, 116.

Abū Bakr Ibn Abī Shaybah, al-Mușannaf, Kitab al-Zakah, Bāb mā qālū fì akhdhi al-'Urud fĩ al-Șadaqah, no. Hadith 10437, 10438, 10439, ed. ke-1 (Riyadh: Maktabah al-Rushd, 1989), j.2, 404.

53 Abū Bakr Aḥmad ibn Ḥusayn Ibn 'Alī al-Bayhāq̄ì, al-Sunan al-Kubrā, Kitab al-Zakāh, Bāb Man Ajāza Akhza al-Qiyām fī al-Zakāwat, no. Hadith 7372 (ed. ke-3, Beirut: Dār al-Kutub al'Ilmiyyah, 2003), 4:189.

54 Hadith riwayat al-Bukhārī, "al-Sahih," Kitab al-Zakāh, Bāb “Ard al-Zakāh, dalam, Fath al-Bārī Sharh Șaḥịh al-Bukhārī, Aḥmad Ibn 'Alī Ibn Hajar al'Asqalānī (Kaherah: Maktabah al-Salāfiyyah, t.t.), 3:366. 


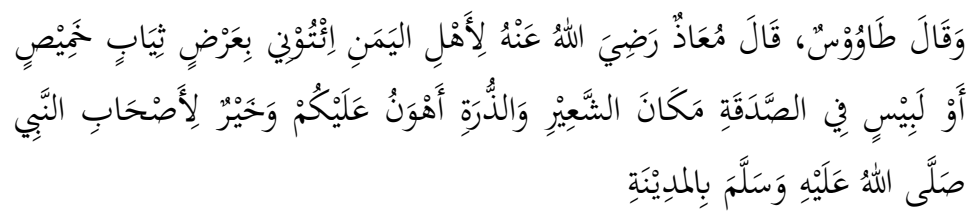

Terjemahan: Tawus berkata: Mu'adh r.a berkata kepada penduduk Yaman: Berikan zakat kalian kepadaku dalam bentuk pakaian khamis atau labis sebagai sebagai ganti daripada gandum dan jagung. Hal itu lebih mudah kalian lakukan, dan lebih berguna bagi sahabat Nabi di Madinah.

Al-'Asqalānī menjelaskan bahawa hadith yang diriwayat oleh al-Bukhari tersebut adalah hadith mu'allaq, tetapi ia telah memaktubkan hadith tersebut sebagai hujjah, yang dapat memberikan status hadith itu menjadi kuat. Kerana ia dapat diperkuat oleh hadith-hadith lain yang ia sebutkan dalam bab itu. ${ }^{55}$ Dari hadith di atas difahamkan bahawa Mu'adh Ibn Jabal mengambil pakaian sebagai ganti jagung dan gandum pada zakat tanaman dan buah-buahan. Difahamkan juga boleh mengambil nilai (wang) pada semua jenis zakat termasuklah zakat fitrah. ${ }^{56}$ Juga seperti riwayat yang menceritakan tentang perintah Abū Bakr kepada Anas Ibn Mālik sebagaimana yang diriwayatkan oleh alBukhārī. Iaitu sebagai berikut:

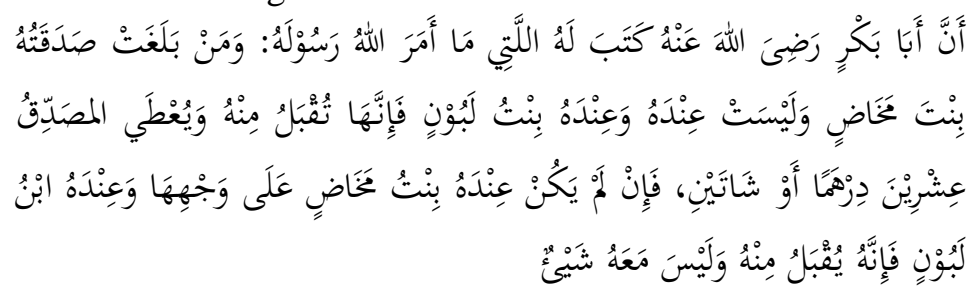

Terjemahan: Sesungguhnya Abū Bakr menulis surat padanya tentang suruhan Allah kepada Rasulnya iaitu: Barang siapa yang wajib membayar zakat seekor Bintu Makhad, tetapi ia tidak memilikinya, ia hanya memiliki Bintu Labun, maka Bintu Labun boleh menggantikan Bintu Makhad dan pembayar zakat akan dibayarkan 20 (dua puluh) dirham atau dua ekor kambing sebagai ganti rugi daripada pembayaran

\footnotetext{
55 Lihat al-Sharqāwī, al-Aḥkām al-Muftarā 'alayha, 157-159.

56 Al-Sharqāwī, al-Ahkām al-Muftarā 'alayhā, 159.
} 
yang lebih. Apabila pembayar zakat tidak memiliki Bintu Makhad dan ia hanya memiliki Ibn Labun, maka ia boleh membayar Ibn Labun dan tiada mendapatkan ganti rugi daripada pembayaran yang lebih. ${ }^{57}$

Amil zakat dalam hal ini mengambil dari pembayar zakat seekor anak unta betina yang umurnya memasuki tahun ketiga, sebagai ganti daripada unta betina yang masuk tahun kedua. Di sini 'amil zakat akan memberikan kepada pembayar zakat sebanyak 20 (dua puluh) dirham ataupun dua ekor kambing sebagai ganti rugi daripada pembayaran unta yang berlebih umurnya. Dalam kedua pilihan tersebut didapati adanya pengalihan daripada jenis unta kepada jenis dirham, atau kambing. Oleh itu, dibolehkan mengambil nilai dari semua jenis zakat. Ulama yang berpegang dengan pendapat ini adalah TTâwūs, Abū Ḥanīfah, al-Bukhārī, dan dari kalangan sahabat adalah 'Umar Ibn al-Khațtāb, 'Abd Allāh Ibn 'Umar, 'Abd Allāh Ibn Mas'ūd, 'Abd Allāh Ibn 'Abbās, dan Mu'adh Ibn Jabāl. ${ }^{58}$

Dalam pada itu, para ulama al-Shāfi'iyyah sendiri juga membolehkan membayar wang pada semua jenis zakat termasuk zakat fitrah, jika keadaan sememangnya menggiring demikian. Keadaan tersebut digambarkan oleh al-Nawāwī seperti tiada didapati jenis barang yang wajib dizakati, dan apabila sultan (kerajaan) menyuruh membayar dengan wang. ${ }^{59}$

Namun begitu, kalangan dayah tradisional Aceh tetap berkeras dan menolak kesahan pembayaran zakat fitrah dengan nilai (wang). Kerana mereka berpandangan bahawa pendapat yang wujud dalam matan-matan kitab ulama al-Shāfi'iyyah yang telah menjadi amalan dan tradisi di dayah dipandang sebagai kebenaran final dalam perkara ini. Sehingga tidak merasa perlu merujuk kepada hadith yang dipedomani sama ada oleh sebahagian alShāfi'iyyah mahupun oleh golongan lain di luar al-Shāfi'iyyah yang membolehkan pembayaran zakat fitrah dengan nilai (wang).

Berasaskan perbahasan sepertimana telah didedahkan dapat terlihat nyata upaya menjadikan rujukan dalam memahami Islam 1448, j.2, 116.

58 Al-Sharqāwī, al-Aākām al-Muftarā 'alayha, 161.

59 Al-Nawāwī, al-Majmū', 5:405.
} 
terhad pada kitab turāth tertentu yang telah menjadi kurikulum dan diiktiraf dalam tradisi secara turun temurun dari para guru sebelumnya. Merujuk kepada kitab turäth yang telah menjadi pedoman dipandang lebih benar daripada langsung merujuk kepada hadith. Kerana apa yang telah wujud dalam kitab turäth adalah ringkasan daripada interpretasi para ulama daripada hadith juga. ${ }^{60}$ Beramal berasaskan apa yang wujud dalam kitab turāth yang muktabar di kalangan mereka adalah sebuah kesimpulan final dari sebuah kebenaran yang tiada dapat bertukar, dan tiada perlu mengambil kira dengan rujukan-rujukan lain yang tidak menjadi kurikulum atau tidak mendapat pengiktirafan ulama kalangan dayah tradisional. Dalam hal ini, maka tiada yang dapat menahan mereka untuk menyalahkan golongan yang berbeza pandangan. ${ }^{61}$ Bahkan berupaya mempengaruhi pihak-pihak yang memiliki peranan untuk menguatkuasakan pendapat yang diamalkan. ${ }^{62}$

\section{Penutup}

Dari perbahasan yang telah diketengahkan dapat diketahui bahawa para ulama di zaman awal Islam hingga zaman moden memandang kitab turäth sebagai hasil karya para ulama dalam memahami agama yang tidak memiliki sebarang iṣmah daripada berlaku kesalahan. Imam mazhab melarang umat mengikuti mereka dan mencela orang mengikuti pendapat mereka jika tidak berasaskan dalil. Abū Hanīfah melarang para pengikut mazhab mengamalkan pendapatnya, sehinggalah mereka mengetahui dalil yang beliau pedomani. Al-Shāfi ‘̄i mengumpamakan orang yang

60 (Guru Senior pada Lajnah Bahsul Masail, Dayah Mudi Mesra Samalanga), dalam temubual dengan pengkaji, 21 Januari 2018; STM (Guru Senior Dayah Mudi Mesra Samalanga), dalam temu bual dengan pengkaji, 21 Januari 2018.

61 Lihat Nuruzzahri, "Implementasikan Secara Masif Fatwa MPU Aceh Tentang Zakat Fitrah" laman sesawang Aceh Tribunnews, dicapai 25 Ogos 2018, http://aceh.tribunnews.com/2017/06/20/implementasikan-secaramassif-fatwa-mpu- aceh-tentang-zakat-fitrah; Abu Mudi: Zakat Fitrah dalam Pandangan Imam al-Shafi‘i dan Imam Abu Hanifah, https://www.youtube.com/watch?v=XV4RrvnUvno, dicapai 20 September 2020; Hukum Zakat Fitrah Dengan Uang [Abiya Muhammad Baidhawi], https://www.youtube.com/watch?v=ED7kXJvFzbg, dicapai 25 Ogos 2018. 
mengamalkan suatu pendapat tanpa wujud dalil sebagai seorang pencari kayu bakar di malam hari yang mengikat tumpukan kayu yang terkadang dalam ikatan itu terdapat ular yang dapat mengigitnya tanpa ia sedar. Berbangkitnya sikap taksub yang diterapkan oleh sebahagian pengikut mazhab sejak empat hijrah hingga zaman kini, tidak dapat dijadikan pedoman bagi mengekalkan perilaku ini. Kerana para ulama yang mengajak kepada islah dan bermanhaj secara benar sentiasa wujud di sepanjang masa.

Jika sememangnya kitab turāth merupakan hasil karya manusia yang tidak mempunyai sebarang jaminan tidak salah ('ișmah) dan tidak juga mempunyai sebarang kesucian (qadāsah), maka bersikap kritis terhadap khazanah yang kaya ini wajib dilakukan. Sama ada dengan cara mengamalkan yang dapat diterima oleh dalil aqli dan tidak bercanggah pula dengan dalil naqli juga bersesuaian dengan kemaslahatan umat, mahupun meninggalkan apa jua yang dapat dipastikan kesalahannya atau tiada lagi bersesuaian untuk diamalkan di zaman kini.

Manakala kalangan ulama dayah tradisional Aceh telah menjadikan rujukan dalam memahami Islam terhad pada kitab turāth tertentu yang telah menjadi kurikulum atau diiktiraf dalam tradisi secara turun temurun. Mereka tiada merasa perlu merujuk langsung kepada hadith. Kerana merujuk kepada kitab turāth yang telah menjadi pedoman dipandang lebih benar daripada langsung merujuk kepada hadith. Bagi kalangan dayah tradisional, apa yang telah wujud dalam kitab turāth adalah ringkasan daripada interpretasi para ulama yang merujuk kepada hadith juga. Maka beramal berasaskan apa yang wujud dalam kitab turāth yang muktabar di kalangan mereka adalah sama dengan beramal dengan hadith. Apa jua yang telah dipilih sebagai amalan, maka ianya menjadi sebuah kesimpulan final bagi sebuah kebenaran yang tiada dapat bertukar.

Kalangan dayah tradisional juga tiada merasa perlu mengambil kira dengan rujukan-rujukan lain yang tidak menjadi kurikulum atau tidak muktabar di kalangan mereka. Sama ada rujukan yang dipedomani oleh sebahagian al-Shāfi'iyyah mahupun oleh golongan lainnya yang berlainan pendapat. Hal ini dalam perkembangannya telah membangkitkan semangat kebanyakan ulama kalangan dayah tradisional untuk bertindak menyalahkan 
golongan yang berbeza pandangan. Bahkan berupaya mempengaruhi pihak-pihak yang memiliki peranan bagi menguatkuasakan pendapat yang diamalkan.

Penuli melihat bahawa tradisi yang telah menjadi amalan ulama dayah tradisional Aceh secara am sangat bercanggah dengan tumpuan para ulama dahulu dan moden yang sentiasa mengajak kepada islah. Berdasarkan apa yang berlaku sepertimana telah diketengahkan, maka penulis mendapati wujud sebuah usaha nyata yang dapat dipandang sebagai upaya pentakdisan kitab turäth yang telah menjadi rujukan muktabar dalam pengajian di dayah tradisional Aceh. Dengan demikian dapat dikatakan, ulama dayah tradisional Aceh memiliki pandangan bahawa kedudukan kitab turāth dalam pengajian ilmu-ilmu keislaman, terutamanya berkenaan dengan masalah fikah, adalah setaraf dengan hadith.

\section{Bibliografi}

'Awwamah, Muhammad. Athār al-Hadìth al-Sharīf fì Ikhtiläf al$\bar{A}$ 'immah al-Fuqahā'. Ed. ke-7, Jeddah: Dār al-Nashar li alTawzī', 2013.

'Iwāḍ, Bakr Zakī. al-Turāth al-Islāmī Bayna al-Taqdīr wa alTaqdīs. Mesir: Wizārat al-Awqāf, 2005.

"Al-Șaḥị̣," Kitab al-Zakāh, Bāb 'Ard al-Zakāh, dalam, Fath alBārī Sharh Șah̄hh al-Bukhārī, Aḥmad Ibn 'Alī Ibn Hajar al'Asqalānī. Kaherah: Maktabah al-Salāfiyyah, t.t. "." L.

"Fatwa MPU Aceh Nombor 13 Tahun 2014 Tentang Zakat Fitrah". Laman sesawang MPU Aceh, dicapai 22 Ogos 2020, https://mpu.acehprov.go.id/.

"Hukum i'adah Shalat Zohor setelah Jumat - Abu Mudi Menjawab". Laman sesawang Youtube, https://www.youtube.com/watch?v=_MTuiRhKKbg, dicapai 20 September 2020.

"Hukum iadah Shalat DZohor Sesudah Shalat Jumat, Muzakarah Ulama Se-Aceh IV", laman sesawang Youtube, https://www.youtube.com/watch?v=CwI6s_lrZOo, dicapai 20 september 2020.

"Hukum Kafarah Shalat dan Puasa | Muzakarah Ulama Se-Aceh VII”. Laman sesawang Youtube, 
https://www.youtube.com/watch?v=yL7yCUw9vOw, dicapai 20 September 2020.

"Hukum Zakat Fitrah dengan Uang [Abiya Muhammad Baidhawi]". Laman sesawang Youtube, https://www.youtube.com/watch?v=ED7kXJvFzbg, dicapai 25 "."L.

Ogos 2018.

"Keputusan Kantor Kementerian Agama Kota Banda Aceh". Laman sesawang Aceh Tribunnews, dicapai 22 Ogos 2020, https://aceh.tribunnews.com/2020/05/11/di-banda-aceh-zakatfitrah-tak-bisa-dibayar-uang-harus-langsung-beras.

"Lajnah Bahtsul Masail Lembaga Pendidikan Islam Ma'hadal Ulum Diniyah Islamiyah". Laman sesawang Ibm Mudimesra, dicapai $25 \quad$ Ogos 2018, http:// lbm.MUDImesra.com//2012/08/diskripsi-masalah.html;

"Wajibkah membayar kafarat orang yang meninggalkan shalat?Tu Sop Jeunieb". Laman sesawang Youtube, https://www.youtube.com/watch?v=4zHC0hLhu40, dicapai 20 September 2020.

Abu Mudi. "Zakat Fitrah dalam Pandangan Imam al-Shafi'i dan Imam Abu Hanifah". Laman sesawang Youtube, https://www.youtube.com/watch?v=XV4RrvnUvno, dicapai 20 september 2020.

Abu Mudi: Zakat Fitrah dalam Pandangan Imam al-Shafi'i dan Imam Abu Hanifah, laman sesawang Youtube. https://www.youtube.com/watch?v=XV4RrvnUvno, dicapai 20 September 2020;

Al-'Alamī, al-Ḥasan. Tajdīd al-Fikr al-Islāmī. Ed. pertama, Kaherah: Maktabah al-Turāth al-Islāmī, 2003.

Al-Albān̄̄, Muḥammad Nāṣir al-Dīn. Al-Hadīth Hujjah bi Nafsihi fi al-'Aqā'id wa al-Aḥkàm. Riyadh: Maktabah al-Ma'ārif wa al-Nashr, 2005.

Al-Albān̄̄, Muḥammad Nāṣir al-Dīn. Al-Tasfiyyah wa alTarbiyyah wa Hajah al-Muslimīn ilayhā. Ed. pertama, Riyadh: Maktabah al-Ma'ārif wa al-Tawzī‘, 2007.

Al-Bayhāqī, Abū Bakr Aḥmad ibn Ḥusayn Ibn 'Alī. Al-Sunan alKubrā, Kitab al-Zakāh, Bāb Man Ajāza Akhza al-Qiyām fī alZakāwat, no. Hadith 7372. Ed. ke-3, Beirut: Dār al-Kutub al'Ilmiyyah, 2003. 
Al-Bukhārī, Muḥammad bin Ismā'̄ill. "Al-Adāb al-Mufrad" dalam Șah̄ị al-Ādāb al-Mufrad, Muhammad Nāṣir al-Dīn al-Albānī. Bab Sakhawat al-Nafs, no. Hadith 208/274. Ed. ke-4, t.tp.: Dār al-Șiddīq, 1997.

Al-Bukhārī, Muḥammad Ibn Ismā'īl. Al-Jāmi' al-Ṣaḥịh. Edisi pertama, Jeddah: Dār Țūq al-Najah, 2001.

Al-Diḥlāwī, Aḥmad Ibn 'Abd al-Raḥīm Shah Waliy Allāh. AlInsaf fì Bayān Asbāb al-Ikhtilaf. Ed. ke-8, Beirut: Dār alNafă'is, 1993.

Al-Hajawī, Muḥammad Ibn al-Hasan. Al-Fikr al-Sami fi Tarīkh alFiqh al-Islāmī. Beirut: al-Maktabah al-'Așriyyah, 2012.

Al-Jawziyyah Ibn al-Qayyīm. I'lam al-Muwaqqi ìn 'an Rabb al'Ālamīn. Kaherah: Dār al-Hadìth, 2004.

Al-Muzānī, Ismā'īl Ibn Yahyāa Ibn Ismā'il. Mukhtașar al-Muzānī fì Furū'al-Shāfi 'iyyah. Ed. 1, Beirut: Dār al-Kutub al-'Ilmiyyah, 1998.

Al-Qarḍāwī, Kayfa nata 'àmal ma'a al-Turāth wa al-Tamadhdhub wa al-Ikhtilaf. Ed. ke-2, Kaherah: Maktabah Wahbah, 2004.

Al-Qarḍāwī, Shari 'ah al-Islām Șaliḥah li al-Tațbiq fì Kullì Zamān wa Makān. Ed. ke-5, Kaherah: Maktabah Wahbah, 1997.

Al-Qarḍāwī, Yūsuf. Al-Marji 'iyyah al-'Ulyā fì al-Islām li alQur'ān wa al-Sunnah. Ed. ke-2, Kaherah: Maktabah Wahbah, 2001.

Al-Qarḍāwī, Yūsuf. Taysīr al-Fiqh li al-Muslim al-Muā'sir fi Daw'i al-Qur'an wa al-Sunnah. Ed. ke-3, Kaherah: Maktabah Wahbah, 2004.

Al-Shāṭib̄̄, Abū Ishạāq Ibrāhīm ibn Mūsā. Al-I'tiṣām, 2: 535; Baca juga 'Umar Sulaymān al-Ashqār, Tarīkh al-Fiqh al-Islāmī. Ed. ke-3, Jordan: Dār al-Nafā'is, 2003.

Dilimunazar "Tulak Breuh (Tradisi Ritual Keagamaan yang Masih Dilaksanakan di Provinsi Aceh)". Laman sesawang Steemit, dicapai $20 \quad$ September 2020, https://steemit.com/culturevulture/@dilimunanzar/tulakbreuh-tradisi-ritual-keagamaan-yang-masih-dilaksanakan-diprovinsi-aceh.

Hukum Zakat Fitrah Dengan Uang [Abiya Muhammad Baidhawi], laman sesawang Youtube. https://www.youtube.com/watch?v=ED7kXJvFzbg, dicapai 25 Ogos 2018. 
Ibn Abī Shaybah, Abū Bakr. Al-Musannaf. Kitab al-Zakah, Bab mā qālū fĩ akhdhi al-'Urud fī al-Șadaqah, no. Hadith 10437, 10438, 10439. Ed. pertama, Riyadh: Maktabah al-Rushd, 1989.

Ibn Muslim, Muslim ibn al-Ḥajjāj. Al-Sahih. Beirut: Ihyā' alTurāth al-'Arabī, t.t.

Miles dan Huberman. Qualitative Data Analysis: A Source Book of New Methods. California: SAGE Publication, 1984.

Muhammad Majid Konting. Kaedah Penyelidikan Pendidikan. Kuala Lumpur: Dewan Bahasa dan Pustaka, t.t.

Nuruzzahri. "Implementasikan Secara Masif Fatwa MPU Aceh tentang Zakat Fitrah". Laman sesawang Aceh Tribunnews, dicapai 25 Ogos 2018, http://aceh.tribunnews.com/2017/06/20/implementasikansecara-massif-fatwa-mpu- aceh-tentang-zakat-fitrah.

Nuruzzahri. "Implementasikan Secara Masif Fatwa MPU Aceh Tentang Zakat Fitrah". Laman sesawang Aceh Tribunnews, dicapai 25 Ogos 2018, http://aceh.tribunnews.com/2017/06/20/implementasikansecara-massif-fatwa-mpu- aceh-tentang-zakat-fitrah;

Sābiq, Al-Sayyīd. Fiqh al-Sunnah. Ed. ke-21, Kaherah: Dār alFath li al-I'lam al-'Arābī, 1999.

Tim Penulis. Buku Pedoman Pengembangan Silabus dan Kurikulum Pendidikan Dayah. Banda Aceh: Badan Pembinaan Pendidikan Dayah Aceh, 2012.

Zahrul Fuadi Mubarrak et al. "Profil Dayah Mudi". Mesjid Raya Samalanga: Lajnah Pengembangan Dakwah MUDI, 2018. 
Lazuardi dan Faisal, Fenomena Pentakdisan Turāth 